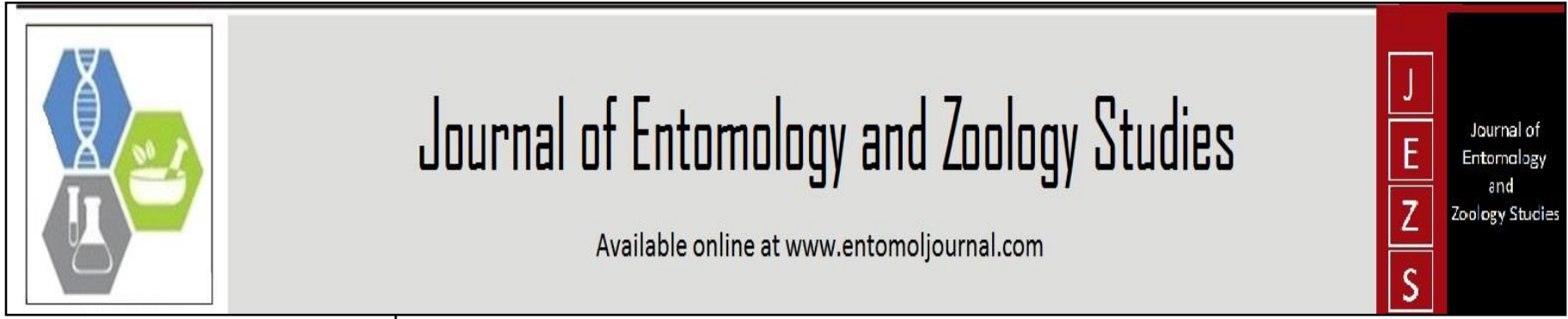

E-ISSN: 2320-7078

P-ISSN: 2349-6800

www.entomoljournal.com

JEZS 2020; 8(4): 1828-1834

(C) $2020 \mathrm{JEZS}$

Received: 27-05-2020

Accepted: 29-06-2020

Bipul Kumar Kakati

Department of Fisheries

Engineering, College of Fisheries,

Assam Agricultural University,

Raha, Nagaon, Assam, India

Inam Akhtar Hussain

Department of Fish Processing

Technology, College of Fisheries,

Assam Agricultural University,

Raha, Nagaon, Assam, India

Umesh Ch. Goswami

Department of Zoology, Gauhati

University, Guwahati, Assam,

India
Corresponding Author: Bipul Kumar Kakati

Department of Fisheries

Engineering, College of Fisheries,

Assam Agricultural University,

Raha, Nagaon, Assam, India

\section{Irradiation effect on microbial and nutritional quality of vacuum packed fermented Phassya Shidal during storage at ambient temperature}

\author{
Bipul Kumar Kakati, Inam Akhtar Hussain and Umesh Ch. Goswami
}

DOI: https://doi.org/10.22271/j.ento.2020.v8.i4ac.7402

\section{Abstract}

The effect of gamma (cobalt-60) irradiation ( 3 and $5 \mathrm{kGy}$ ) on the microbial safety and biochemical quality of fermented Phassya Shidal, which was vacuum-packed in polyethylene bags and stored under ambient temperature was studied by measuring microbiological and biochemical changes in six months of storage. Gamma irradiation had significant effects $(P<0.05)$ on the reduction of microbial populations making the product safe and free from the possibilities of food poisoning. Coliform count was detected in the case of irradiated samples, only after the fourth month of storage. No yeasts and moulds were detected in irradiated samples at $3 \mathrm{kGy}$ until the end of $5^{\text {th }}$ month and at $5 \mathrm{kGy}$ at the end of the $3^{\text {rd }}$ month of storage. Salmonella spp. were not detected in all irradiated and control samples throughout the storage period. The moisture content of control and irradiated Shidal samples ( $3 \mathrm{kGy} \& 5 \mathrm{kGy}$ ) was recorded as $38.80 \%, 35.86 \%$ and $34.46 \%$, respectively and showed significant decrease $(P<0.05)$ after irradiation. There is increase of protein, fat and ash content after treatment. Though the biochemical analysis showed little loss in the nutritional quality of Shidal after treatment and the subsequent storage period, yet the products remained in an acceptable condition. As the higher doses of gamma irradiation effect the changes of nutritional quality more, therefore, low dose irradiation i.e. 3 kGy may be recommended as a safe preservation method for the fermented fish product Shidal.

Keywords: Irradiation, microbial safety, nutritional quality, fermented fish product, Phassya Shidal, storage

\section{Introduction}

Fermented fish product Shidal is popular in the North eastern part of India, because of its unique falvour and aroma, which is prepared exclusively from soft fin swamp barb, Puntius sophore (Hamilton, 1822). But recently, it is also prepared from one estuarine dried fish product prepared from the Gangetic hairfin anchovy, Setipinna phasa (Hamilton, 1822), and become popular in the region, because of comparatively less price without compromising its typical flavor and taste. Fermented Setipinna phasa is locally known as Phassya Shidal, Telash maach etc., which is available in the markets of the region ${ }^{[1]}$. Phassya Shidal available in the markets of the North eastern states of India had a high nutritive value and could serve as a significant source of essential amino acids and polyunsaturated fatty acids, particularly n-3 series of essential fatty acids (EPA and DHA). But, the problems encountered with the market sample of Shidal were their susceptibility to spoilage mainly due to high microbial load, contamination with spoilage and pathogenic microorganisms like Staphylococcus aureus, Streptococcus spp. and Escherichia coli, which are generally, associated with public health hazards and lipid oxidation ${ }^{[2]}$.

At present, there is the need to apply a technique that could yield high quality product of Phassya Shidal with low microbial load to minimize the problem of spoilage, food poisoning and to increase the shelf life of the product. Food irradiation carried out under conditions of good manufacturing practice, was recommended as an effective, widely applicable food processing method, judged to be safe on extensive available evidence that can reduce the risk of food poisoning, control food spoilage and extend the shelf-life of foods without detriment to health and with minimal effect on nutritional or sensory quality. This view has been endorsed by international bodies such as the World Health Organization, the Food and Agricultural Organization and Codex Alimentarius ${ }^{[3]}$. 
Radiation sensitive gram negative bacteria are mostly responsible for spoilage of fishery products. Therefore, the reduction of spoilage causing microorganisms by low level of radiation leads to an extension of shelf life of fishery Products ${ }^{[4]}$. Food irradiation provides safety and extends the shelf life of fisheries products because of its high effectiveness in inactivating pathogenic and spoilage microorganisms without deteriorating product quality ${ }^{[5]}$. The aim of this study was to determine the effect of gamma irradiation on microbial safety and nutritional quality in low-dose ( 3 and $5 \mathrm{kGy}$ ) during six months storage of Phassya Shidal in vacuum packed in polythene bag at ambient temperature.

\section{Materials and Methods \\ Collection of sample \& treatment of gamma irradiation}

Phassya Shidal was collected from the production centres of Nagaon and Morigaon district of Assam and brought to the laboratory in aseptic condition. The samples were divided in to three lots for different treatments $(3 \mathrm{kGy}$ and $5 \mathrm{kGy}$ gamma irradiation), sealed in vacuum packed polyethylene (300 gauge) bag. The samples were then placed separately in a styrofoam boxes which were placed in single layer around in irradiated chamber. One sample was kept untreated and considered as control. Irradiation was done in a ${ }^{60} \mathrm{Co}$ irradiator at Bhabha Atomic Research Centre (BARC), Tromby, Mumbai, India and samples were subjected to $3 \mathrm{kGy}$ and 5 $\mathrm{kGy}$ irradiation. After irradiation, samples were stored at ambient temperature for further study. The different irradiated fermented Phassya Shidal was then analyzed for their proximate composition (protein, fat, minerals and moisture), biochemical and microbial quality at one month interval for six months storage time.

\section{Microbiological analysis}

An amount of $10 \mathrm{~g}$ of muscle from different parts of the sample was collected aseptically and macerated with $90 \mathrm{ml}$ sterile saline $(0.85 \%)$. The microbial quality of the samples was determined after making serial dilution in the same diluents. The microbial quality of Phassya Shidal was determined by the methods of APHA and USFDA ${ }^{[6,7]}$.

Total plate count on Nutrients Agar (NA) for 48 hours at $37^{\circ}$ $\mathrm{C}$, yeast and moulds on Potato Dextrose Agar (PDA) incubated for 72 hours at $37^{\circ} \mathrm{C}$, for MPN Coliform by multiple tube fermentation procedure using EC broth and Lauryl Sulfonate tryptose (LST) broth, Escherichia coli on Tergitol-7 (T-7) Agar for 48 hours at $37^{\circ} \mathrm{C}$, For enumeration of Salmonella spp., 25g of fish sample homogenized with 225 $\mathrm{ml}$ of lactose broth and incubated at $37^{\circ} \mathrm{C}$ for 24 hours for pre enrichment. $1 \mathrm{ml}$ of pre-enriched sample will be transferred to $10 \mathrm{ml}$ of Selenite cystine broth and $10 \mathrm{ml}$ of Tetrathionate broth and incubated at $37^{\circ} \mathrm{C}$ for 24 hours for enrichment. A loopful of enriched sample is streaked on Bismuth Sulphite Agar (BSA) or Xylose Lysine Deoxycholate Agar (XLDA) and incubated at $37^{\circ} \mathrm{C}$ for 48 hours.

\section{Biochemical analysis}

Moisture, crude protein, crude fat, ash and non protein nitrogen (NPN) content of the Phassya Shidal were determined by AOAC methods ${ }^{[8]}$, standard methods were used for the determination of salt soluble nitrogen ( $\mathrm{SSN})^{[9]}$, total volatile base nitrogen (TVB-N) content according to the Conway's micro diffusion method ${ }^{[10]}$, peroxide value (PV) was determined from the lipid extract using iodometric method ${ }^{[11]}$, free fatty acids (FFA) value was estimated following chloroform extraction method ${ }^{[12]}$. $\mathrm{pH}$ was determined using a pH meter (Sartorius Make), after homogenizing $5 \mathrm{~g}$ of fish sample with $45 \mathrm{ml}$ distilled water.

\section{Statistical analysis}

Statistical analysis was done by performing one way ANOVA at 5\% level using SPSS-16.0 software and differences $(P<0.05)$ among the means were compared using the Duncan's Multiple Range Test (SPSS for Windows. Release 11.5. Chicago: IL: SPSS Inc, 2000) ${ }^{[13] .}$

\section{Results and Discussion Microbial quality}

The values of total plate count, coliforms count, yeasts and moulds count, MPN E. coli and Salmonella spp. detection of non-irradiated (control) and irradiated (3 kGy and $5 \mathrm{kGy}$ ) Phassya Shidal during storage at ambient temperature are shown in Table 1. Initial total bacterial count of the control sample was $4.90 \log \mathrm{cfu} / \mathrm{g}$, whereas the counts in irradiated samples at $3 \mathrm{kGy}$ and $5 \mathrm{kGy}$, were not detectable. Microbial load of irradiated samples at $3 \mathrm{kGy}$ until the end of the first month and in case of $5 \mathrm{kGy}$, until the end of the second month were below detection level. The lowest microbial load at the end of the sixth month of storage was related to irradiated samples at $3 \mathrm{kGy}$ and found $2.35 \mathrm{log} \mathrm{cfu} / \mathrm{g}$. There was a significant differences $(P<0.05)$ in total bacterial count between the treatments and between storage days of the samples. The alteration in microbial population and composition as a result of irradiation depends on the dose of irradiation, storage temperature, packaging conditions and fish species used ${ }^{[14]}$. Total bacterial count of degutted fresh Pampus chinensis was affected by gamma radiation $(3,5$ and $8 \mathrm{kGy})$ in combination with low temperature $\left(-20^{\circ} \mathrm{C}\right)$ storage. In their study, initial bacterial load of control was maximum $\left(1.3 \times 10^{4} \mathrm{cfu} / \mathrm{g}\right)$ followed by $3 \mathrm{kGy}$ irradiated fishes $\left(2 \times 10^{2}\right.$ cfu/g) and at $5 \mathrm{kGy}$ and $8 \mathrm{kGy}$, the samples were completely sterilized resulting in no bacterial growth ${ }^{[15]}$. Further, the combination of frozen storage plus irradiation resulted in greater overall reductions of microbial loads, extending shelf life of chicken meat for commercial application and critical conditions ${ }^{[16]}$.

In the present experiment, yeasts and moulds were not detected in irradiated samples at $3 \mathrm{kGy}$ until the end of $5^{\text {th }}$ month and at $5 \mathrm{kGy}$ until the end of the $3^{\text {rd }}$ month of storage. Because of some metabolite production in lipid oxidation and bacterial growth reactions in $3 \mathrm{kGy}$ and $5 \mathrm{kGy}$, the population of yeasts and moulds increased in the fourth and fifth months of storage. Significant differences $(P<0.05)$ was observed in yeast and moulds count between the treatments and between storage days in the Shidal samples. Similarly, yeasts and moulds were not detected in farmed rainbow trout (Oncorhynchus mykiss) fillets irradiated at $3 \mathrm{kGy}$ throughout the frozen storage time and in irradiated samples at 1 and 5 $\mathrm{kGy}$, until the end of the third month of frozen storage ${ }^{[17]}$. It has been stated that yeasts and moulds are sensitive to the irradiation process because of their large genomic structure ${ }^{[18]}$. But, It was also reported that the gamma irradiation $(3,5$ and $8 \mathrm{kGy})$ in combination with low temperature $\left(-20^{\circ} \mathrm{C}\right)$ storage of degutted fresh Pampus chinensis, the total mould count (TMC) increased with the increase of storage period ${ }^{[15]}$. In the present study, coliform were detected at the end of the second month and showed the count to be $<1 \log \mathrm{cfu} / \mathrm{g}$ in control samples the product, whereas the coliform count were detected in case of irradiated samples, only after the fourth 
month of storage. But, the count was less in irradiated Shidal samples at $3 \mathrm{kGy}(<1)$ compared to irradiated at $5 \mathrm{kGy}(1.15$ $\log \mathrm{cfu} / \mathrm{g})$. Salmonella spp. we're not detected in all irradiated and control sample throughout the storage. There was significant differences $(P<0.05)$ in the coliform count between the control and irradiated samples and between storage days.

It was reported that no coliforms were detected in irradiated $(1.5$ and $3 \mathrm{kGy})$ camel meat during refrigerated storage at $3 \pm 1{ }^{\circ} \mathrm{C}^{[19]}$. The optimum dose of gamma radiation in order to decrease coliforms and especially for elimination of Salmonella spp. of red meat was obtained at $3 \mathrm{kGy}$. With an increase in irradiation, the number of coliform decreased [16]. Radiation sensitivity of non-spore forming pathogenic bacteria such as Salmonella in meat and fishery products is well documented ${ }^{[17,19,20]}$. Like other gram negative bacteria, Salmonella and coliforms have a very low resistance to radiation. Therefore, elimination of these bacteria by radiation could be beneficial to the preservation of fish products in view of the major role that these species play in the spoilage of fish ${ }^{[17]}$.

\section{Biochemical quality}

The proximate composition of non-irradiated and irradiated samples of Phassya Shidal is presented in Table 2. The moisture content of control and irradiated Shidal samples (3 $\mathrm{kGy}$ and $5 \mathrm{kGy}$ treated) was recorded as $38.80 \%, 35.86 \%$ and $34.46 \%$, respectively and showed significant decrease $(P<0.05)$ after irradiation. Whereas, the protein, fat and ash content was increased after treatment, but there were no significant differences $(P>0.05)$ between control and irradiated samples, with exception in ash content in the sample. It was reported that no significant differences were observed in moisture, protein, fat and ash content, when meatballs were irradiated using a ${ }^{60} \mathrm{Co}$ irradiation source (with the dose of 1, 3, 5 and $7 \mathrm{kGy}$ ) and stored (1,2 and 3 weeks) at $4^{0} \mathrm{C}{ }^{[3]}$. In another experiment, no significant changes in the protein, fat, carbohydrate and ash content had been observed in shrimp, exposed to low-dose irradiation [21]. Irradiation could lead protein to multiple excitations/ionizations within the molecules. The absorbed energy could be transferred that may make one site more sensitive and thus may induce bond breakage, thus leading to the formation of more soluble protein. Therefore, the greater the irradiation dose applied, the greater the protein that will be extracted ${ }^{[22]}$.

The biochemical quality of control and irradiated Phassya Shidal samples were evaluated by determining salt soluble nitrogen $(\mathrm{SSN})$, non protein nitrogen $(\mathrm{NPN})$, total volatile base nitrogen (TVB-N) \& $\mathrm{pH}$ to know the protein quality (Table 3) and peroxide value (PV), free fatty acid (FFA) for lipid quality (Table 4). The SSN value was lower in the case of irradiated Shidal samples compared to control and showed significant difference $(P<0.05)$ between treatments. The higher the doses of irradiation, the lower the SSN value. Again, the SSN content decreased significantly $(P<0.05)$ with the storage period (Fig 1). The NPN and TVB-N content showed significant $(P<0.05)$ increase after irradiation and similar trend was observed during the storage period (Fig. $2 \&$ 3 ). But, the value was more in case of $5 \mathrm{kGy}$ irradiated sample than $3 \mathrm{kGy}$ and non-irradiated sample indicating the effect of irradiation on protein quality of Shidal. Lower the dose of irradiation, lower effect on protein quality.

In the present study, Phassya Shidal samples were vacuum packaged before irradiation to minimize the oxidative changes. The peroxide value and free fatty acids value were higher in irradiated Shidal samples than non-irradiated Shidal and the values of PV and FFA were increased significantly $(P<0.05)$ with storage time (Fig $4 \& 5)$. Irradiation of lipids and fats may produce carbonyl groups and other oxidation products, such as peroxides. It is generally assumed that irradiation in the presence of oxygen increases oxidative changes. Rancidity is a sensory effect markedly perceptible when lipids are irradiated in the presence of oxygen ${ }^{[23]}$.

The $\mathrm{pH}$ value of control sample was increased significantly $(P<0.05)$ during storage. It might be due to production of volatile bases during biochemical and microbiological changes in the samples. The $\mathrm{pH}$ values remain acidic in all samples throughout the storage period. Irradiation effect on $\mathrm{pH}$ of control and irradiated Phassya Shidal was not significant $(P>0.05)$ during treatment (Fig. 6). Irradiation works mainly on water molecules present in the food matrix. It does not interfere the acidity or alkalinity of the food product ${ }^{[24]}$.

Table 1: Microbial flora count fermented Phassya Shidal (0, 3 and 5 kGy treated) during storage at ambient temperature

\begin{tabular}{|c|c|c|c|c|c|c|c|c|}
\hline \multirow{2}{*}{ Microbial flora } & \multirow{2}{*}{$\begin{array}{c}\text { Dose } \\
(k G y)\end{array}$} & \multicolumn{7}{|c|}{ Storage times (month) } \\
\hline & & 0 & 1 & 2 & 3 & 4 & 5 & 6 \\
\hline \multirow{3}{*}{$\begin{array}{l}\text { Total count }(\log \\
\mathrm{cfu} / \mathrm{g})\end{array}$} & 0 & $4.90 \pm 1.04^{\mathrm{ab}}$ & $4.70 \pm 0.87^{\mathrm{ab}}$ & $4.80 \pm 0.47^{\mathrm{abx}}$ & $4.90 \pm 0.40^{\mathrm{abx}}$ & $5.17 \pm 1.02^{\mathrm{ax}}$ & $5.00 \pm 0.75^{\text {ax }}$ & $5.47 \pm 0.65^{\mathrm{ax}}$ \\
\hline & 3 & ND & ND & $1.32 \pm 0.30^{\text {bcy }}$ & $1.00 \pm 0.00^{\mathrm{cz}}$ & $2.00 \pm 0.17^{\mathrm{az}}$ & $2.20 \pm 0.14^{\mathrm{az}}$ & $2.35 \pm 0.25^{\mathrm{az}}$ \\
\hline & 5 & ND & ND & ND & $2.20 \pm 0.15^{\text {by }}$ & $2.80 \pm 0.16^{\text {by }}$ & $3.17 \pm 0.12^{\text {ay }}$ & $3.70 \pm 0.28^{\text {ay }}$ \\
\hline \multirow{3}{*}{$\begin{array}{l}\text { MPN Coliform (log } \\
\text { cfu/ } 100 \mathrm{~g})\end{array}$} & 0 & ND & ND & ND & $<1$ & $1.10 \pm 0.00^{\mathrm{b}}$ & $1.30 \pm 0.10^{\mathrm{bx}}$ & $1.47 \pm 0.00^{\mathrm{ax}}$ \\
\hline & 3 & ND & ND & ND & ND & ND & $<1$ & $<1$ \\
\hline & 5 & ND & ND & ND & ND & ND & $1.00 \pm 0.00^{\text {ay }}$ & $1.15 \pm 0.06^{\text {ay }}$ \\
\hline \multirow{3}{*}{$\begin{array}{l}\text { Yeasts and Moulds } \\
\quad(\log \mathrm{cfu} / \mathrm{g})\end{array}$} & 0 & ND & ND & ND & $1.21 \pm 0.20^{\mathrm{b}}$ & $1.14 \pm 0.08^{\mathrm{bx}}$ & $1.27 \pm 0.19^{\text {ax }}$ & $1.30 \pm 0.30^{\mathrm{ax}}$ \\
\hline & 3 & ND & ND & ND & ND & ND & ND & $1.00 \pm 0.00^{\mathrm{yz}}$ \\
\hline & 5 & ND & ND & ND & ND & $1.00 \pm 0.00^{\mathrm{ay}}$ & $1.14 \pm 0.00^{\mathrm{bxy}}$ & $1.23 \pm 0.11^{\mathrm{ay}}$ \\
\hline
\end{tabular}

MPN E. coli and Salmonella spp. were absent in the irradiated Phassya Shidal throughout storage period at ambient temperature

$\mathrm{ND}=$ not detected; a-c means within a row, which are not followed by a common superscript letter (s) are significantly different $(P<0.05)$; $\mathrm{x}-\mathrm{z}$ means within a column, which are not preceded by a common superscript letter(s) are significantly different $(P<0.05)$.

Table 2: Proximate composition of non-irradiated and irradiated Phassya Shidal

\begin{tabular}{|c|c|c|c|c|}
\hline Proximate Composition (\%), N=3 & Control & Treated with 3 kGy & Treated with 5 kGy & $\boldsymbol{P}$ value \\
\hline Moisture & $38.80 \pm 1.20^{\mathrm{a}}$ & $35.86 \pm 0.95^{\mathrm{b}}$ & $34.46 \pm 1.10^{\mathrm{c}}$ & 0.03 \\
\hline Protein & $28.15 \pm 0.80^{\mathrm{a}}$ & $28.31 \pm 0.28^{\mathrm{a}}$ & $28.55 \pm 0.60^{\mathrm{a}}$ & 0.85 \\
\hline Fat & $23.25 \pm 1.15^{\mathrm{a}}$ & $24.76 \pm 0.66^{\mathrm{a}}$ & $25.58 \pm 0.51^{\mathrm{a}}$ & 0.43 \\
\hline Ash & $7.95 \pm 0.25^{\mathrm{b}}$ & $8.02 \pm 0.18^{\mathrm{b}}$ & $8.56 \pm 0.66^{\mathrm{a}}$ & 0.05 \\
\hline
\end{tabular}

All values are the mean \pm standard deviation; Different letters $(\mathrm{a}-\mathrm{c})$ in the same line indicate significant differences $(P<0.05)$. 
Table 3: Quality changes of protein of non-irradiated and irradiated Phassya Shidal during storage at ambient temperature

\begin{tabular}{|c|c|c|c|c|}
\hline Parameters N=3 & Storage days & Control & 3 kGY treated & $5 \mathrm{kGY}$ treated \\
\hline \multirow{7}{*}{$\mathrm{pH}$} & 0 & $6.4 \pm 0.03^{\mathrm{cq}}$ & $6.3 \pm 0.05^{\text {bu }}$ & $6.1 \pm 0.02^{\text {au }}$ \\
\hline & 30 & $6.3 \pm 0.02^{\mathrm{cp}}$ & $6.2 \pm 0.02^{\mathrm{bt}}$ & $6.0 \pm 0.04^{\text {at }}$ \\
\hline & 60 & $6.4 \pm 0.07^{\mathrm{cq}}$ & $6.1 \pm 0.06^{\mathrm{bs}}$ & $5.9 \pm 0.07^{\text {as }}$ \\
\hline & 90 & $6.2 \pm 0.11^{\mathrm{bp}}$ & $6.0 \pm 0.05^{\mathrm{ar}}$ & $5.9 \pm 0.10^{\text {ar }}$ \\
\hline & 120 & $6.4 \pm 0.03^{\mathrm{cq}}$ & $6.0 \pm 0.02^{\text {br }}$ & $5.8 \pm 0.02^{\mathrm{ar}}$ \\
\hline & 150 & $6.5 \pm 0.06^{\mathrm{cr}}$ & $5.9 \pm 0.04^{\text {bq }}$ & $5.6 \pm 0.06^{\mathrm{aq}}$ \\
\hline & 180 & $6.7 \pm 0.02^{\mathrm{cs}}$ & $5.8 \pm 0.07^{\mathrm{bp}}$ & $5.4 \pm 0.08^{\text {ap }}$ \\
\hline \multirow{7}{*}{$\mathrm{SSN}(\%$ of total $\mathrm{N})$} & 0 & $46.5 \pm 0.25^{\mathrm{cs}}$ & $45.2 \pm 0.32^{\mathrm{bs}}$ & $43.7 \pm 0.41^{\text {as }}$ \\
\hline & 30 & $45.4 \pm 0.42^{\text {br }}$ & $44.7 \pm 0.27^{\mathrm{bs}}$ & $42.6 \pm 0.25^{\text {ars }}$ \\
\hline & 60 & $44.8 \pm 0.33^{\mathrm{cr}}$ & $43.6 \pm 0.44^{\mathrm{br}}$ & $42.0 \pm 0.21^{\text {ar }}$ \\
\hline & 90 & $44.1 \pm 0.28^{\mathrm{bq}}$ & $42.7 \pm 0.61^{\text {ar }}$ & $41.8 \pm 0.36^{\mathrm{ar}}$ \\
\hline & 120 & $42.9 \pm 0.15^{\text {bpq }}$ & $42.1 \pm 0.10^{\mathrm{bqr}}$ & $40.8 \pm 0.44^{\text {ar }}$ \\
\hline & 150 & $41.4 \pm 0.35^{\text {bp }}$ & $40.8 \pm 0.41^{\mathrm{bq}}$ & $38.1 \pm 0.32^{\mathrm{aq}}$ \\
\hline & 180 & $40.3 \pm 0.67^{\mathrm{cp}}$ & $38.7 \pm 0.52^{\text {bp }}$ & $36.9 \pm 0.75^{\text {ap }}$ \\
\hline \multirow{7}{*}{ NPN $(\%)$} & 0 & $2.5 \pm 0.25^{\text {ap }}$ & $2.6 \pm 0.37^{\text {ap }}$ & $2.9 \pm 0.18^{\text {ap }}$ \\
\hline & 30 & $2.8 \pm 0.54^{\text {apq }}$ & $2.8 \pm 0.75^{\text {ap }}$ & $3.0 \pm 0.27^{\text {ap }}$ \\
\hline & 60 & $3.1 \pm 0.47^{\text {apq }}$ & $3.1 \pm 0.85^{\text {ap }}$ & $3.3 \pm 0.62^{\text {apq }}$ \\
\hline & 90 & $3.2 \pm 0.22^{\mathrm{aq}}$ & $3.3 \pm 0.60^{\text {ap }}$ & $3.6 \pm 0.45^{\mathrm{aq}}$ \\
\hline & 120 & $3.3 \pm 0.51^{\text {aq }}$ & $3.5 \pm 0.58^{\text {apq }}$ & $3.8 \pm 0.66^{\mathrm{abq}}$ \\
\hline & 150 & $3.6 \pm 0.75^{\mathrm{aq}}$ & $3.8 \pm 0.63^{\text {apq }}$ & $4.0 \pm 0.35^{\mathrm{aqr}}$ \\
\hline & 180 & $3.7 \pm 0.40^{\mathrm{aqr}}$ & $4.1 \pm 0.48^{\mathrm{aq}}$ & $4.5 \pm 0.75^{\mathrm{abr}}$ \\
\hline \multirow{7}{*}{ TVB-N (mg\%) } & 0 & $105.0 \pm 0.65^{\text {ap }}$ & $106.3 \pm 0.47^{\text {ap }}$ & $108.0 \pm 0.53^{\mathrm{bp}}$ \\
\hline & 30 & $107.5 \pm 0.29^{\mathrm{aq}}$ & $108.2 \pm 0.65^{\text {ap }}$ & $110.4 \pm 0.65^{\mathrm{bq}}$ \\
\hline & 60 & $110.1 \pm 0.41^{\text {ar }}$ & $112.3 \pm 0.80^{\mathrm{abq}}$ & $114.6 \pm 1.23^{\mathrm{br}}$ \\
\hline & 90 & $112.5 \pm 0.55^{\text {as }}$ & $115.0 \pm 0.39^{\mathrm{br}}$ & $118.0 \pm 0.70^{\mathrm{cs}}$ \\
\hline & 120 & $117.4 \pm 0.35^{\text {at }}$ & $118.5 \pm 0.67^{\text {as }}$ & $121.5 \pm 0.75^{\mathrm{bt}}$ \\
\hline & 150 & $120.0 \pm 0.72^{\mathrm{au}}$ & $121.8 \pm 0.44^{\text {at }}$ & $126.0 \pm 1.10^{\text {bu }}$ \\
\hline & 180 & $121.4 \pm 0.45^{\text {au }}$ & $124.4 \pm 0.50^{\text {bu }}$ & $130.7 \pm 1.21^{\mathrm{cv}}$ \\
\hline
\end{tabular}

All values are the mean \pm standard deviation; a-d means within a row, which are not followed by a common superscript letter (s) are significantly different $(P<0.05)$; p-t means within a column, which are not preceded by a common superscript letter(s) are significantly different $(P<0.05)$.

Table 4: Quality changes of fat of non-irradiated and irradiated Phassya Shidal during storage at ambient temperature

\begin{tabular}{|c|c|c|c|c|}
\hline Parameters $\mathrm{N}=3$ & Storage days & Control & $3 \mathrm{kGY}$ treated & $5 \mathrm{kGY}$ treated \\
\hline \multirow{7}{*}{$\mathrm{PV}$ (meq $\mathrm{O}_{2} / \mathrm{kg}$ of fat) } & 0 & $52.6 \pm 1.10^{\text {ap }}$ & $54.5 \pm 0.40^{\text {abp }}$ & $57.0 \pm 0.63^{\mathrm{bp}}$ \\
\hline & 30 & $53.8 \pm 0.85^{\text {ap }}$ & $56.2 \pm 0.55^{\mathrm{bq}}$ & $59.2 \pm 0.31^{\mathrm{cq}}$ \\
\hline & 60 & $55.4 \pm 0.76^{\mathrm{aq}}$ & $59.0 \pm 0.65^{\text {br }}$ & $61.6 \pm 0.52^{\mathrm{cqr}}$ \\
\hline & 90 & $57.8 \pm 1.05^{\mathrm{aq}}$ & $61.1 \pm 1.18^{\mathrm{br}}$ & $64.5 \pm 1.30^{\text {cr }}$ \\
\hline & 120 & $59.1 \pm 1.11^{\mathrm{aqr}}$ & $64.3 \pm 1.35^{\mathrm{bs}}$ & $67.7 \pm 0.35^{\mathrm{cs}}$ \\
\hline & 150 & $60.3 \pm 0.45^{\text {ar }}$ & $67.0 \pm 0.50^{\mathrm{bt}}$ & $70.2 \pm 0.41^{\mathrm{ct}}$ \\
\hline & 180 & $59.6 \pm 0.35^{\mathrm{aqr}}$ & $66.5 \pm 0.47^{\mathrm{bt}}$ & $69.7 \pm 0.20^{\mathrm{cs}}$ \\
\hline \multirow{7}{*}{ FFA ( $\%$ as oleic acid) } & 0 & $75.0 \pm 1.21^{\text {ap }}$ & $76.6 \pm 0.65^{\text {ap }}$ & $79.4 \pm 1.15^{\mathrm{abp}}$ \\
\hline & 30 & $76.3 \pm 0.48^{\text {ap }}$ & $78.1 \pm 0.52^{\mathrm{bp}}$ & $80.4 \pm 0.57^{\mathrm{cp}}$ \\
\hline & 60 & $78.7 \pm 0.57^{\text {apq }}$ & $81.2 \pm 0.57^{\mathrm{bpq}}$ & $83.0 \pm 0.78^{\mathrm{cq}}$ \\
\hline & 90 & $80.1 \pm 1.05^{\mathrm{aq}}$ & $83.3 \pm 0.74^{\mathrm{abq}}$ & $87.5 \pm 0.49^{\text {cr }}$ \\
\hline & 120 & $82.4 \pm 0.65^{\mathrm{aq}}$ & $85.5 \pm 0.66^{\text {br }}$ & $88.3 \pm 0.84^{\text {cr }}$ \\
\hline & 150 & $85.5 \pm 0.49^{\mathrm{ar}}$ & $87.0 \pm 0.70^{\text {ar }}$ & $90.7 \pm 0.74^{\mathrm{bs}}$ \\
\hline & 180 & $87.2 \pm 0.60^{\text {as }}$ & $89.2 \pm 0.47^{\mathrm{bs}}$ & $92.6 \pm 0.37^{\mathrm{cs}}$ \\
\hline
\end{tabular}

All values are the mean \pm standard deviation; a-d means within a row, which are not followed by a common superscript letter $(\mathrm{s})$ are significantly different $(P<0.05)$; $\mathrm{p}$-t means within a column, which are not preceded by a common superscript letter(s) are significantly different $(P<0.05)$. 


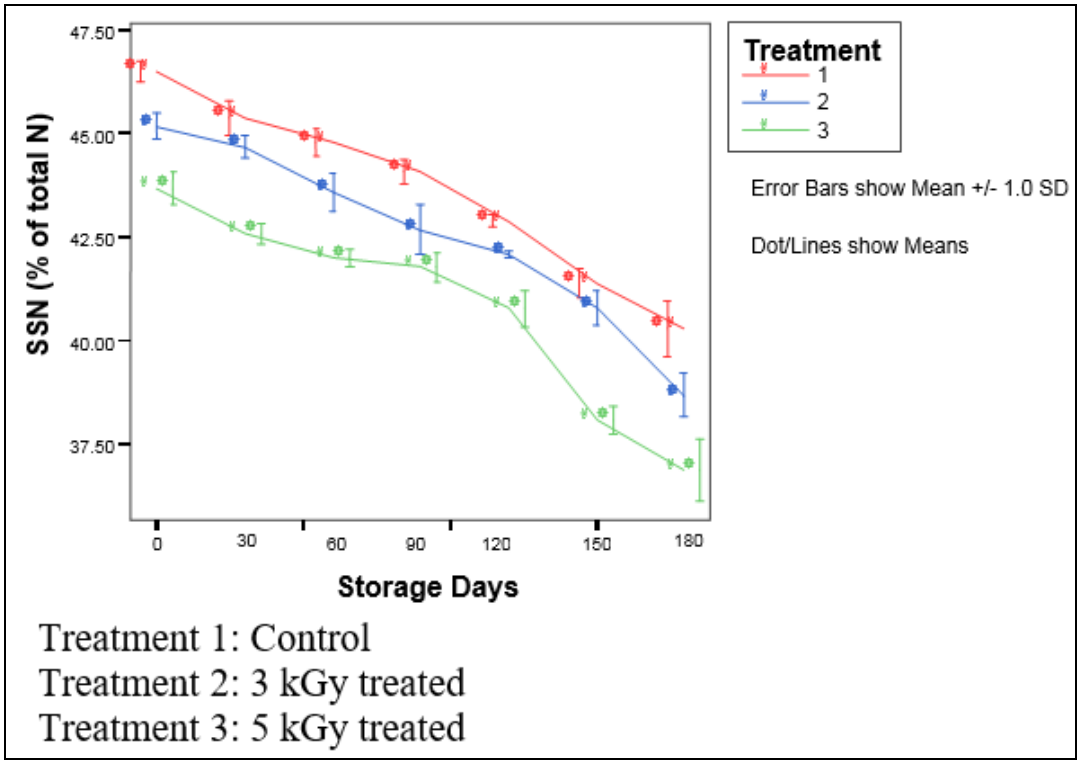

Fig 1: Changes in SSN content of control and irradiated Phassya Shidal during storage

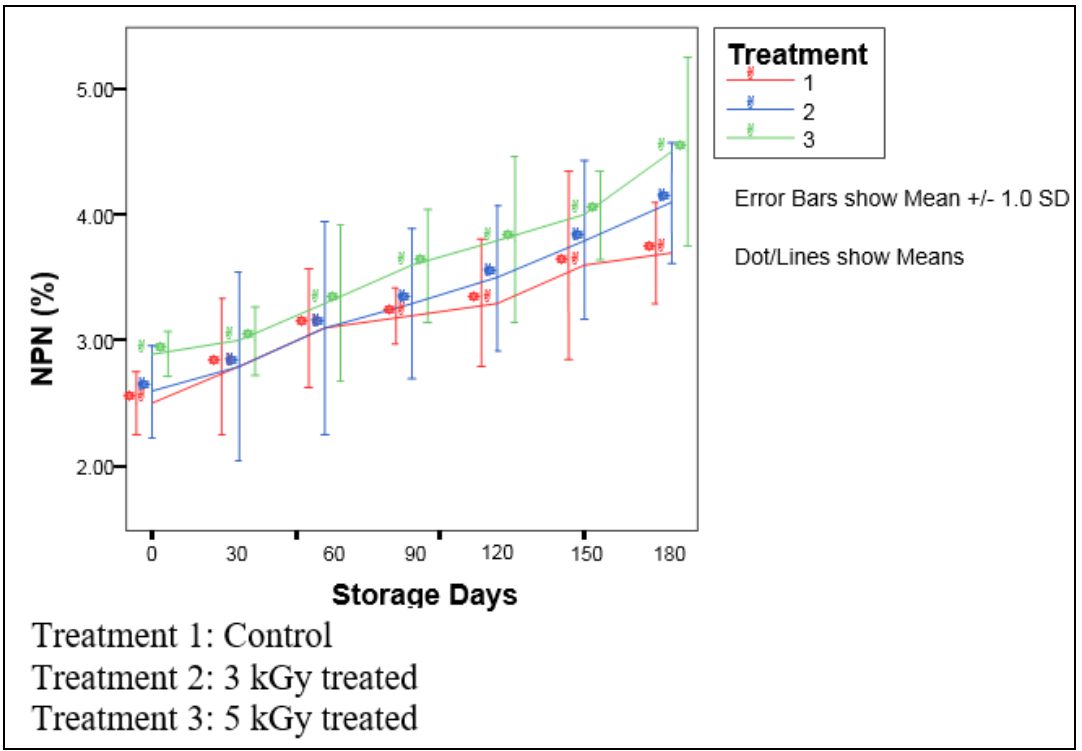

Fig 2: Changes in NPN content of control and irradiated Phassya Shidal during storage

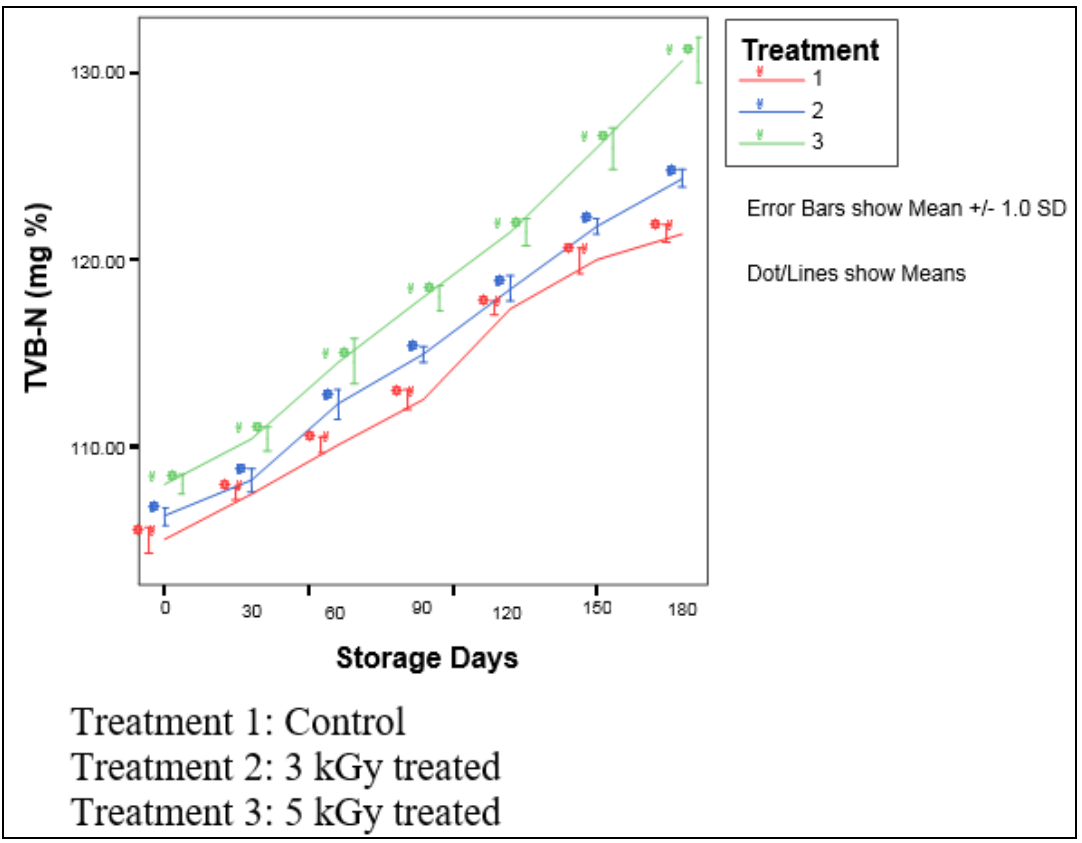

Fig 3: Changes in TVB-N content of control and irradiated Phassya Shidal during storage 


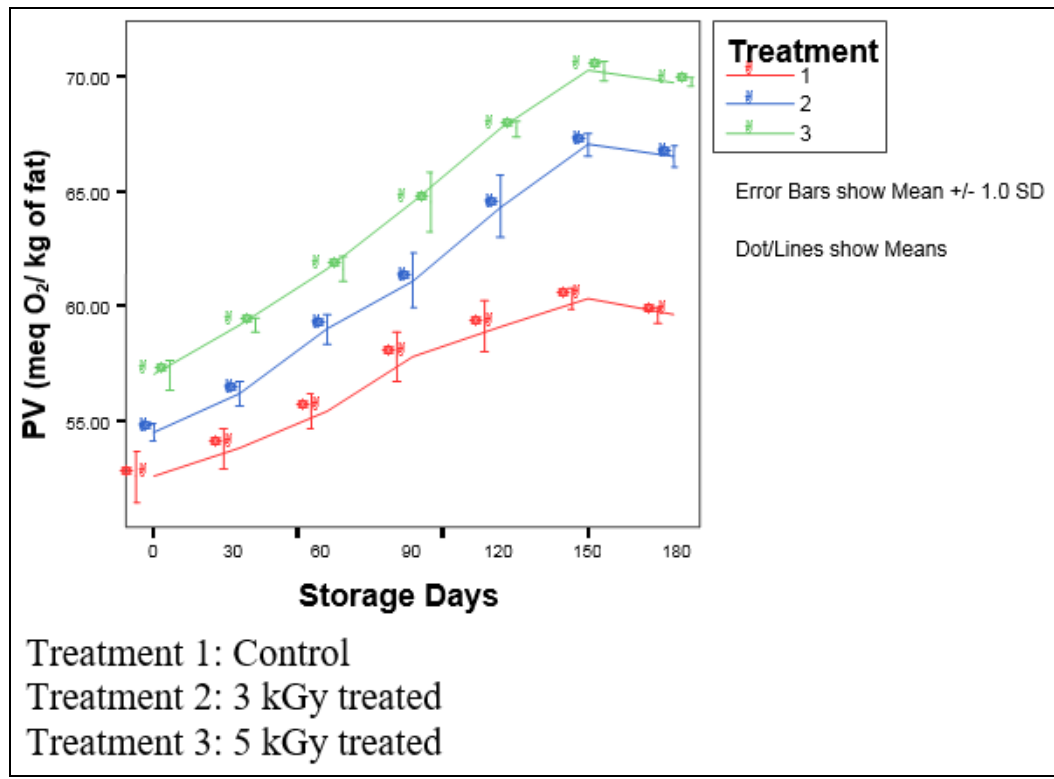

Fig 4: Changes in PV of control and irradiated Phassya Shidal during storage

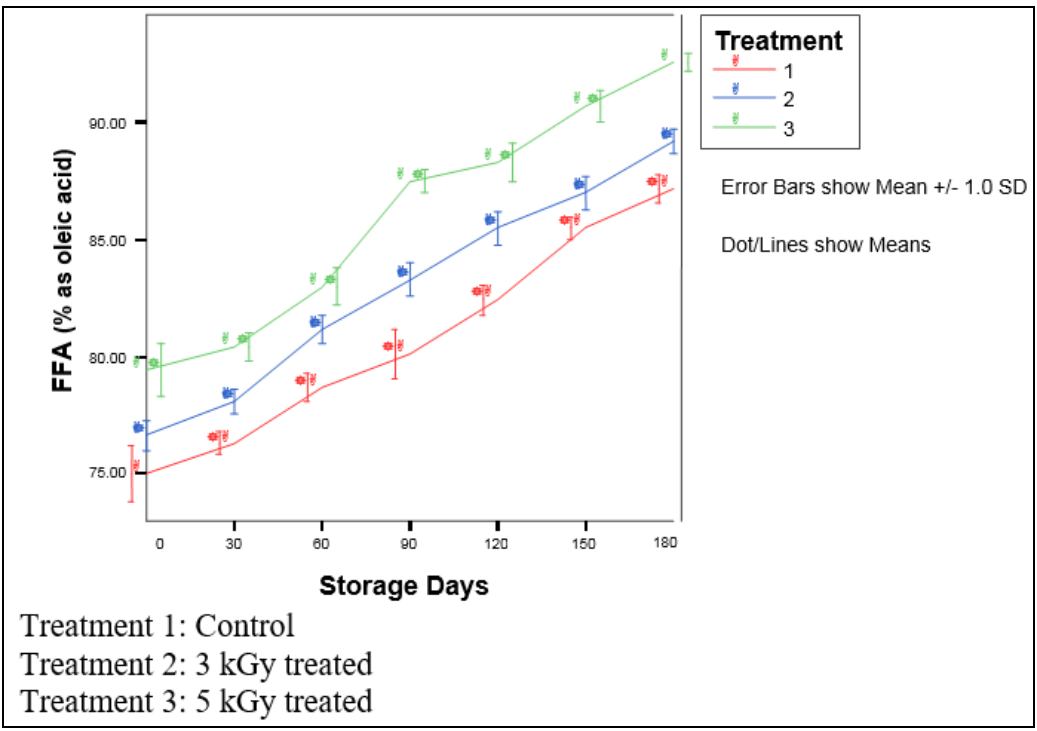

Fig 5: Changes in FFA of control and irradiated Phassya Shidal during storage



Fig 6: Changes in $\mathrm{pH}$ of control and irradiated Phassya Shidal during storage 


\section{Conclusion}

Gamma irradiation as a preservative method has been gaining popularity in the recent years, as it produces safe food product for consumers. In the present experiment, gamma irradiation with doses of $3 \mathrm{kGy}$ and $5 \mathrm{kGy}$, had a significant effect on the keeping quality of Phassya Shidal during storage in vacuum packaged polythene bag at ambient temperature. Irradiation process reduced the microbial load in the treated Shidal to a greater extent, making the product safe and free from the possibilities of food poisoning. As the higher doses of gamma irradiation effect more in the changes of nutritional quality, therefore, low dose irradiation i.e. $3 \mathrm{kGy}$ may recommended as a safe preservation method for fermented fish products Shidal and irradiation may be a good alternative of fish preservation method.

\section{References}

1. Majumdar RK. Phassya Shidal-A traditional fermented fish product of NE India. Fishing Chimes. 2007; 27(5):30-31.

2. Kakati BK, Goswami U. Nutritional microbial and sensory quality evaluation of fermented Setipinna phasa, Hamilton, 1822 (Phassya Shidal), marketed in North-east India. Journal of Applied and Natural Science. 2017; 9(1):237-244.

3. Geegel U. Changes in some physic-chemical properties and fatty acids composition of irradiated meatballs during storage. Journal of Food Science \& Technology. 2013; 50(3):505-513.

4. Mahapatra AK, Muthukumarappan K, Julson JL. Application of ozone, bacteriocin and irradiation in food processing: Review Critical Review of Food Science and Nutrition. 2005; 45:447-461.

5. Özden O, Erkan N. Impacts of gamma radition on nutritional components of minimal process cultured sea bass (Dicentrarchus labrax). Iranian Journal of Fisheries Sciences. 2010; 9(2):265-272.

6. APHA. Compendium of methods for the Microbiological Examination of foods (Edited by Speak, ML), American Public Health Association Inc., New York, 2001.

7. USFDA. Bacteriological Analytical Manual, $8^{\text {th }}$ Edn. (Revised) Association of Official Analytical Chemist, Washington DC, 2001.

8. AOAC. Official Methods of Analysis, $17^{\text {th }}$ Edn. Association of Official Analytical Chemicals, Washington, DC, USA, 2000.

9. Dyer WJ, French HV, Snow JM. Proteins in fish muscle, extraction of protein fraction in flesh. Journal of the Fisheries Research Board of Canada. 1950; 7d(10):585593.

10. Conway EJ. Micro diffusion Analysis and Volumetric Error. Crossby, Lockwood \& Sons, London, 1947.

11. Jacobs MB. The chemical analysis of foods and food products. New York Krieger Publishing Co. Inc, USA, 1958, 393-394.

12. Olley T, Loveren JA. Phospholipid hydrolysis of cod flesh stored at various temperatures. Journal of the Science of Food and Agriculture. 1960; 11(11):644-652.

13. SPSS. Statistical Package for Social Sciences for Windows, Release10. Chicago, II., SPSS Inc, 2000.

14. Özden Ö, Inugur M, Erkan N. Effect of different dose gamma radiation and refrigeration on the chemical and sensory properties and microbiological status of aqua cultured sea bass (Dicentrarchus labrax). Radiation
Physics and Chemistry. 2007; 76:1169-1178.

15. Ahmed K, Hasan M, Alam J, Ahsan N, Islam M, Akter MS. The effect of gamma radiation in combination with low temperature refrigeration on the chemical, microbiological and organoleptic changes in Pampus chinensis (Euphrasen, 1788). World Journal of Zoology. 2009; 4(1):9-13.

16. Sedeh FM, Arbabi K, Fatolahi H, Abhari, M. Using gamma irradiation and low temperature on microbial decontamination of red meat in Iran. Indian Journal of Microbiology. 2007; 47:72-76.

17. Moini S, Tahergorabi R, Seyed Vali H, Rabbani M Tahergorabi Z, Feas X et al. Effect of gamma radiation on the quality and shelf life of refrigerated rainbow trout (Oncorhynchus mykiss) fillet. Journal of Food Protection. 2009; 72(7):1419-1426.

18. Fallah AA, Saei-Dehkordi S, Rahnama, M. Enhancement of microbial quality and inactivation of pathogenic bacteria by gamma irradiation of ready-to-cook Iranian barbecued chicken. Radiation Physics and Chemistry. 2010; 79(10):1073-1078.

19. Fallah AA, Tajik H, Razavi Rohani M, Rahnama M. Microbial and sensory characteristics of camel meat during refrigerated storage as affected by gamma irradiation. Pakistan Journal Biological Science. 2008; 11(6):894-899.

20. Badr HM. Use of irradiation to control food borne pathogens and extend the refrigerated market life of rabbit meat. Meat Science. 2004; 67:541-548.

21. Anon. Irradiation of Shrimp: Summary of Submission Process, Food and Nutrition, www.hc-sc.gc.ca, 2010.

22. Urbano WM. Food Irradiation, Academic Press, 1986.

23. Santos AF et al., Determinação da dose de irradiação gamma para reduzir a população de Salmonella spp em carne de frango. Ciência e Tecnologia de Alimentos. 2003; 23(2):200-205.

24. Mojica ERE, Nato-Jr AQ, Ambas MET, Feliciano CP, Francisco MLDL, Deocaris CC. Application of irradiation as pretreatment method in the production of fermented fish paste. Journal of Applied Sciences Research. 2005; 1(1):90-95. 